\title{
THE SUBJECTS OF THE ADMINISTRATIVE PROCESS
}

\section{Popovich Ye. M.}

\section{INTRODUCTION}

The variety of administrative and procedural activities involves a significant number of its subjects. First of all, this is due to the fact that the administrative and procedural sphere covers almost all aspects of society.

In the General theory of law, the subject of law is a participant in public relations, endowed with rights and obligations and having two characteristics: social (participation in public relations as a separate, able to develop and implement a single will of a personified subject) and legal (recognition by legal norms of its ability to be a bearer of rights and obligations, to participate in legal relations).

Participants of administrative process can be characterized as citizens, other persons, collectives of citizens and organizations in the person of their representatives having the rights and certain duties allowing them to participate in consideration of administrative cases for the purpose of protection of the rights and legitimate interests or the rights and legitimate interests of the person, collective or organization which they represent, The necessity of differentiation of these concepts is explained by the fact that in the course of clarifying the General and characteristic inherent to each group of subjects, there is an opportunity to clarify important questions regarding the characteristics of the powers of leading actors, on the one hand, and the rights and duties of participants of process, on the other. This underscores the need for the leading actors of the process to protect and respect the rights and legitimate interests of its participants through their actions and decisions. Thus, the legal status of each of groups of subjects of administrative process becomes clear, possibilities of protection of the rights and legitimate interests of its participants expand.

\section{General characteristics of subjects of administrative procedure law}

In the General theoretical understanding, the subject is recognized (from the Latin subjectus - the one who is at the heart), the carrier of subjectpractical activity and knowledge (an individual or a social group), the source of activity aimed at the object.

In turn, in the theory of law, the subject of law is a person (natural or legal) that by law has the ability to have and implement directly or through a representative of the rights and legal obligations (that is, legal personality). 
Legal personality, which includes legal capacity and capacity, are endowed with both subjects of material administrative-legal relations and subjects of procedural administrative-legal relations ${ }^{1}$.

Administrative-procedural legal capacity is the ability to have legal rights and obligations in the administrative process. It is recognized for all citizens of Ukraine, foreigners, stateless persons, as well as for public authorities, other state bodies, authorities of the Autonomous Republic of Crimea, local authorities, their officials and officials, enterprises, institutions, organizations that are legal entities.

Administrative procedural legal capacity arises in citizens from the moment of their birth and is terminated by death. For legal entities, it arises from the moment of their creation and ends with their liquidation. To participate in the administrative process, in addition to the General administrative procedural legal capacity, it is also necessary to have a specific administrative procedural legal capacity, that is, in this particular case.

In order to personally participate in the consideration of an administrative case, it is not enough to have only administrative procedural legal capacity. Possession of administrative procedural capacity is also necessary for the participant of the case ${ }^{2}$.

Administrative-procedural capacity is the ability to personally exercise their administrative procedural rights and obligations, including to entrust the conduct of the case to a representative.

It belongs to individuals who: 1) have reached the age of majority; 2) are not recognized by the court as incapacitated.

It may also belong to individuals until the age of majority in disputes over public relations, in which they are in accordance with the law can independently participate.

Administrative procedural capacity is also vested in public authorities, authorities of the Autonomous Republic of Crimea, their officials and officials, enterprises, institutions, organizations (legal entities) $)^{3}$.

The component of the procedural capacity is the administrative-procedural delict worthiness, i.e. the ability of the subject to bear legal responsibility for the violation of administrative-procedural norms.

It is necessary to distinguish the concepts of "subject of administrative process" and "subject of administrative-procedural legal relations".

${ }^{1}$ Kuzmenko O. Course of administrative responsibility. Textbook. Kyiv: Yurinkom Inter, 2015. $568 \mathrm{p}$.

${ }^{2}$ The code of Ukraine on administrative offences dated 7 December 1984, No. 8073-x. URL: http://zakon4.rada.gov.ua/laws/show/80731-10

3 Administrative and legal protection of citizens ' rights: studies.-method. possib./ K. Afanasiev et al.; Lugan. state University EXT. cases to them. E. Didorenko. Lugansk : RIO LGUSD them. E. Didorenko, 2011. 279 p. 
The subject of the administrative process has the potential ability to enter into administrative-procedural legal relations. In a particular case, he may not be a party to these legal relations.

The subject of administrative-procedural legal relations is the actual participant of legal relations in the sphere of public administration, that is, he necessarily participates in them.

\section{Classification of subjects of administrative procedure law}

At present, the Institute of subjects of administrative process is seriously studied in the theory of administrative process. The theorists of the administrative process proposed different classifications of subjects of procedural legal relations, depending on what is invested by each of the theorists in the content of the administrative process. For example, S. Mahina proposed such a classification:

Three groups of subjects take part in the management process.

The first group - "endowed with their own powers (the party that governs) - the President, senior officials, the highest Executive authorities".

The second group is the subjects, which are subject to their own influence (controlled party). These include individuals and legal entities that are not endowed with their own powers in the field of management.

In the third group, the author includes subjects who simultaneously have their own powers and are under managerial influence. These are officials, state and municipal employees, structural units of public authorities, etc.

As for the administrative process as a form of coercive influence, as N.G. Salisheva notes, its subjects can be divided into two groups ${ }^{4}$.

The first group includes entities directly interested in the results of the legal process, whose interests and subjective rights are subject to protection by all procedural methods and techniques.

The second group includes the leading actors who perform their functions in the interest of others, for the purpose of a legal and reasonable decision on the case.

V. Sorokin divides subjects of administrative process on individualcitizens, foreign citizens, persons without citizenship; collective-Executive authorities, the enterprises, establishments, public associations, the state and municipal employees.

M. Tishchenko defines participants of process as citizens, other persons, collectives of citizens and the organizations represented by their representatives who are allocated with the rights and bear certain duties

${ }^{4}$ Administrative law: textbook / Y. Bytyak, etc.; the NAT. Yuri. Acad. Ukraine them. Yaroslav The Wise. Kharkiv: Pravo, 2010. 624 p. 
allowing them to participate in consideration of administrative cases for the purpose of protection of the rights and legitimate interests or the rights and legitimate interests of the persons represented by them, collectives of citizens or the organizations, and also to promote implementation of administrative process 5 .

It defines organizers (leading subjects) as subjects of administrative process acting for the purpose of conducting process, capable to make decisions on business on the state-power basis.

The group of organizers (leading subjects) is heterogeneous. The relation of this or that body (official) to law enforcement, i.e. the decision of business has essential value. The body (official) deciding the case leads not only at the decision stage. It has enough procedural possibilities to provide production at other stages: powers of procedural control, authorization of the procedural actions which are carried out by other leading subjects, ensuring execution of the decision. Of the organizers, he offers to call the wire. Therefore, other leading entities, depending on the degree of publicity of the legal case (jurisdictional, positive), are more or less dependent on the management.

In jurisdictional cases, the leading subjects are given greater freedom in the enforcement of power in relation to interested persons. in other proceedings, such leading subjects turn to the wire for the sanction of power influence. In the latter case, the procedural status of the leading actors approaches the status of stakeholders.

Finally, all the leading actors can be attributed to the composition of the participants, since the implementation of compulsory procedural actions in the vast majority of cases is carried out with the approval of the leadership.

Therefore, the scientist proposes to divide the subjects of production into groups and participants. And the latter - on the leading actors, stakeholders and persons contributing to the consideration of the case.

Wire. The subject of the process is the management body as a whole (for example, the Ministry of economic development and trade of Ukraine). Procedural functions of the Ministry in production are carried out by its management, legal management, other divisions. At the same time, the Deputy Minister acts as a guide in the case. It should be considered a legal form realist procedural functions leads to such a level of administrative organization as a Ministry.

At the same time, the functions of the Commission can rely not only on the bodies on behalf of which their senior officials act. An official to whom such a right is specifically delegated may also ensure the proceedings in an

${ }^{5}$ Kolpakov V. Administrative-tort process: studies. benefit. / Kolpakov V., Gordeev V. Kharkiv: Kharkiv legal, 2012. 227 p. 
administrative case. Therefore, the leadership should be understood as bodies and officials ${ }^{6}$.

The judge performs procedural actions that are of a key nature during a certain stage, the previous stage of the decision of the case. As a rule, it is the expert who appoints the examination, demands evidence from interested parties, communicates with the authorities of foreign countries. If the judicial or administrative authorities of one party to an international Treaty, in connection with their consideration of violations of customs legislation and regulations, request it, the customs authorities of the other party to such Treaty may authorize their employees as experts and witnesses in such judicial or administrative proceedings.

However, some procedural actions cannot be committed or authorized even by wire. It is a question of restriction of the rights and freedoms of citizens which can be applied only by court, or about measures which can be used only by the Central office of system of a certain service.

First, administrative detention. It is applied judicially in order to:

1) the transfer of a person to a competent authority established by law on the basis of a reasonable suspicion that he has committed an offence or if there are reasonable grounds to consider it necessary to prevent him from committing an offence or fleeing after it has been committed;

2) the prevention of the illegal entry of a person into the country or the detention of a person to whom measures are taken for the purpose of deportation or extradition;

3) application of Supervisory measures of educational character to the minor or his lawful detention of the minor for the purpose of its delivery to the competent authority established by the law; 4) prevention of distribution of infectious diseases, lawful detention of mentally ill, alcoholics, addicts or vagrants.

Secondly, according to part 1 of article 30 of the Constitution of Ukraine, inspection of objects in housing or other possession of a person is applied in court.

Third, only a higher authority (the Central office of the Ministry, another Central Executive authority) decides to extend the terms of production (for example, the extension of the terms of execution of the decision on the land dispute).

V. Kolpakov distinguishes five groups of subjects of administrative process: 1) citizens; 2) Executive and administrative bodies and structural parts of their apparatus; 3 ) associations of citizens and their bodies, and also

${ }^{6}$ Kuzmenko O. Course of administrative responsibility. Textbook. Kyiv: Yurinkom Inter, 2015. 568 p. 
bodies of self-organization of the population which have administrative and procedural legal personality; 4) civil servants, employees of local governments, officials, are allocated with administrative and procedural rights and duties; 5) other state bodies and their officials ${ }^{7}$.

A special place among them is occupied by citizens.

They, first, they are the bearers of rights and obligations (including administrative and procedural) in any branch of public administration (economic, socio-cultural, administrative, political);

- secondly, the specificity of the General legal status of citizens generates in all other subjects of the administrative process the obligation to ensure compliance with their rights;

- thirdly, unlike other subjects, citizens are not competent to solve administrative cases (if not endowed with special powers, but in this case they already belong to another category of subjects);

- fourthly, citizens cannot enter into administrative and procedural relations directly with each other.

Executive and administrative bodies as subjects of the administrative process are characterized primarily by the fact that they solve individual cases. However, the administrative and procedural legal personality of Executive and administrative bodies varies. It is divided into General, branch and special.

General legal personality are those bodies whose competence includes the solution of a wide range of cases, regardless of their sectoral competence. These include, for example, local state administrations, bodies of local self-government.

Branch legal personality are bodies whose tasks include the resolution of cases within the industry. These are, for example, departments, services, departments of ministries.

Special legal personality have bodies created specifically to solve a narrow range of cases. For example, the administrative Commission of the district state administration.

The relevant normative acts determine the administrative and procedural legal personality of officials, civil servants, employees of local selfgovernment bodies. Its features are due to two circumstances ${ }^{8}$ :

- first, it is important that civil servants belong to a certain category of managers or specialists (the legal personality of a Manager is broader than that of a specialist);

7 ComSoc A. Administrative process of Ukraine: textbook. no./ ComSoc A. T., V. Bevzenko R. Miller. Kiev : A Precedent, 2007. 531 p.

${ }^{8}$ Scientific and practical commentary of the Code of Ukraine on administrative offences / G. Kalyuzhny, N. Inshin, I. Shopina, etc. - fifth Edition, with amendments and additions as of September 10, 2013 Kyiv: Alerta, 2013. 976 p. 
- secondly, the content of official rights and duties plays a significant role. Therefore, the head of the district state administration and the head of Department of the Ministry belong to one category-the third, but, it is clear that their legal personality different.

Other state bodies and officials provided for by law have special administrative and procedural legal personality.

So, district (city) judges individually consider a number of cases on administrative offenses (Art. $221 \mathrm{CAO}$ ), in bodies of Prosecutor's office production on complaints and statements of citizens is conducted.

The Ukrainian Parliament Commissioner for human rights exercises parliamentary control over the observance of constitutional rights and freedoms of man and citizen and the rights of everyone in Ukraine and has the right to invite officials and officers, citizens of Ukraine, foreigners and stateless persons for verbal or written explanations regarding circumstances that are verified by the case.

In the literature the administrative-procedural legal personality of such state bodies as the national security and defense Council of Ukraine, the Central election Commission and others is considered.

Given the current trends in the development of administrative-procedural legislation and theoretical studies of scientists- system of subjects of administrative process can be presented as follows:

- Citizens, foreign citizens and stateless persons;

- State bodies, enterprises and institutions;

- Public associations and other non-governmental organizations, enterprises and institutions;

- Civil servant;

- Employees of public associations and other non-state formations.

Citizens, foreign citizens and stateless persons form the most numerous group of subjects of administrative process. They act in the administrative process as:

- persons who have initiated an administrative case before the body entitled to its decision in connection with the exercise of their rights or performance of duties;

- administrative dispute, have declared in the body authorised to consider administrative proceedings, requirements for the protection of violated or disputed rights, or the party to whom a claim to the authority about the violation or contesting its rights applicant;

- third parties, that is, a person who has made an independent claim on the subject of the dispute, has not made such a claim, but joined the requirements of one of the parties;

- authorized representative, unless otherwise provided by law; 
- the person brought to administrative responsibility;

- the victim, i.e. the person to whom moral, physical or material harm is caused by an administrative offense;

- a person protecting the rights and interests of others;

- witness, interpreter, expert.

In each of these cases, the legal status of a citizen as a participant in the administrative process has its own specifics, which is due to the role that the citizen performs in the process. However, the legislation enshrines the General procedural rights and obligations, recognizing the administrativeprocedural legal capacity and administrative-procedural capacity of citizens.

State bodies, enterprises and institutions. They have a special role in the sphere of public-legal relations. Legislative (representative) authorities, Executive authorities, courts, Prosecutor's office are to some extent endowed with the rights to resolve specific administrative cases.

State bodies, first of all Executive authorities, can act in the administrative process as:

- bodies considering and deciding an administrative case;

- bodies that initiate proceedings in connection with the exercise of their functions before the body entitled to its resolution;

- parties to an administrative dispute, third parties;

- bodies protecting the rights and legitimate interests of other persons (bodies, institutions, organizations).

State enterprises, institutions, associations and other legal entities may participate in the administrative process on the same grounds as state bodies.

Public associations and other non-governmental organizations, enterprises and institutions may act in the administrative process as: non-state formations (organizations, etc.), which initiated an administrative case in connection with the exercise of their functions before the body that has the right to solve it; parties to an administrative dispute; third parties; organizations that protect the rights and interests of other persons; organizations that solve an administrative case in cases and within the limits established by law.

Civil servant. As subjects of administrative process employees can act as: the official who considers and makes decisions on administrative business; the official who initiated administrative business in connection with implementation of the functions assigned to it before the body having the right to its permission; the parties of administrative legal dispute; the representative of state body, the state enterprise, establishment; the third persons; the person brought to disciplinary or administrative responsibility.

Employees of public associations and other non-state formations. Nonstate employees may act in the administrative process as: an employee who initiated an administrative case in connection with the exercise of official 
functions before a body entitled to its resolution; parties to an administrative dispute; a representative of a public Association or other non-state formation, third parties; an employee who considers and makes decisions on an administrative case in cases provided for by law; the person brought to administrative responsibility in the cases specified in the law ${ }^{9}$.

In cases stipulated by the legislation, representatives of public associations, organizations, for example, trade unions, consumer protection societies and the like may participate in the administrative process.

\section{Features of the administrative-procedural status of citizens}

Citizens, first of all, are carriers of the rights and duties (including administrative and procedural) in any branch of the public-administrative sphere (economic, socio-cultural, administrative, political);

- secondly, the specificity of the General legal status of citizens generates in all other subjects of the administrative process the obligation to ensure compliance with their rights;

- thirdly, unlike other subjects, citizens are not competent to solve administrative cases (if they are not endowed with special powers, but in this case they already belong to another category of subjects);

- fourthly, citizens cannot enter into administrative and procedural relations directly with each other.

The administrative-procedural status of a citizen should be considered in a broad and narrow sense, which relate to each other as a whole and a part.

In a narrow sense, it is a set of legal qualities that the state confers on a citizen. First of all, these are rights and obligations. The attitude of the state towards citizens in the sphere of administrative law and procedure is also expressed through other legal categories, such as legal guarantees of the rights, freedoms and obligations of citizens. In other words, everything that legislates the position of a citizen in society, mediates the types of ties and relations between the state and the citizen, should be understood as the legal status of a citizen in a broad sense.

Thus, in a narrow sense, the administrative-procedural status of a citizen is a set of legal possibilities of citizens regulated by administrative-procedural norms as carriers of subjective rights and obligations to participate in administrative-procedural activity.

In a broad sense, the administrative-procedural status of a citizen is a set of all legal means fixed in the administrative-procedural norms, with the help of which the position of a citizen in the administrative process is determined.

9 Administrative and legal protection of citizens ' rights: studies.-method. possib./ K. Afanasiev et al.; Lugan. state University EXT. cases to them. E. Didorenko. Lugansk : RIO LGUSD them. E. Didorenko, 2011. 279 p. 
It is advisable to allocate the following types of administrative and procedural status of a citizen: General administrative and procedural status of citizen, which is characteristic for all types of industries; special (special) the status of specific industries; single administrative and procedural status of a particular participant in the particular circumstances. Realization of the individual status of the citizen is connected with stages, stages of productions and separate procedural actions.

Illustrating this provision, we note, for example, that absolutely for all citizens participating in the process, the law provides for the right to receive information, at the constitutional level, the right to appeal in court the actions of officials. These rights are characteristic of the entire administrative process, and therefore, they can be attributed to the General administrative-procedural status of a citizen, analyzing which, we come across a special procedural status. Thus, in the proceedings on administrative offenses, we observe a set of procedural rights and obligations characteristic of this production and enshrined by the legislator in an independent section of the administrative Code.

As elements of the administrative-procedural status of a citizen include: a) administrative-procedural rights; b) administrative-procedural legal capacity; c) administrative-procedural capacity; d) administrative-procedural freedoms; e) administrative-procedural duties; e) administrative-procedural legitimate interests.

Through the mechanism of subjective rights, a broader category of human and civil rights is realized.

Administrative and procedural rights of citizens can be divided into groups (types). Depending on the stage of the administrative process: the rights associated with the possibility of initiating an administrative process on the initiative of the citizen (in particular, the right to receive specific information from the competent authorities, the right to submit an application, etc.); the rights associated with informing the citizen about the reasons and purpose of involving him in the administrative process initiated by other entities. In particular, these are the rights to familiarize with the case materials, to obtain an explanation of the grounds for applying coercive or administrative preventive measures to it; the rights that enable a citizen to influence the course and results of the administrative process. As the largest group, administrative procedural rights are most fully enshrined by the legislator, although to a greater extent this applies to jurisdictional proceedings. For example, the right to give explanations, to present evidence, to file petitions, etc; the rights connected with possibility of the appeal by the citizen of actions and decisions of competent authorities and officials. 
Depending on the possibility of personal exercise of administrative and procedural rights by a citizen, it is possible to distinguish the rights that a citizen realizes independently; the rights that a citizen delegates to other persons (legal representatives) in accordance with the law.

Finally, the method steps include: administrative procedure law, the implementation of which the citizen should make certain actions, for example to declare the petition for granting translator; administrative procedure law, the implementation of which the citizen does not need to actually act (e.g. the right to consideration of the application within the statutory period specific).

Administrative-procedural rights of the second type, as a rule, are not fixed in normative-legal acts. In most cases, they arise from the procedural obligations of other subjects of the administrative process.

It is obvious that the ratio of administrative and procedural rights of citizens and their respective responsibilities of the competent authorities and officials is the most important factor in the reality and effectiveness of the Arsenal of procedural rights of the individual ${ }^{10}$.

Administrative-procedural legal capacity, as a rule, is associated with the implementation of procedural rights of citizens in specific legal relations. But, a number of administrative and procedural rights are enshrined directly in the sources of law, regardless of specific legal relations (an example of such a right is the right to appeal to the Executive authorities for assistance in the implementation of subjective rights). Implemented in accordance with the will of the citizen, they give rise to certain legal relations. In connection with these legal relations, the citizen has procedural rights due to them.

\section{Administrative and procedural status of individual subjects of the administrative process}

In the existing classifications of subjects of procedural legal relations, proposed by theorists of administrative process, all subjects of administrativeprocedural activity are taken into account.

However, the proceedings on administrative offences have a certain list of subjects whose functions and competence are clearly defined by the norms of the Code of Ukraine on administrative offences and other legal acts of Ukraine.

According to this, according to the nature of the procedural status of the subjects of the said proceedings can be divided into three groups: 1) the subjects who decide the case (subjects of jurisdiction); 2) the subjects against whom the case is decided (interested subjects); 3 ) auxiliary participants in the proceedings (disinterested subjects).

${ }^{10}$ Kuzmenko O. Administrative justice in Ukraine: textbook. Kyiv: Atika, 2007. 156 p. 
The first group always includes state bodies and their officials.

The second group can include almost any subjects, both bodies and persons.

The third includes witnesses, victims, experts, translators, lawyers and the like. The specific list of participants in administrative-procedural relations depends on the type of administrative proceedings.

Subjects of administrative jurisdiction are public administration bodies and their officials who carry out administrative and jurisdictional activities related to the decision of a particular case of an administrative offense and the issuance of the relevant law enforcement act.

The Executive bodies of councils can be referred to the public bodies exercising jurisdictional activity, because, in accordance with section II of the Constitution of Ukraine and article 5 of the Law "on local self-government in Ukraine", these are components of the local self-government system in Ukraine, which satisfy the public interests. Although the Executive bodies of councils can also be defined as local self-government bodies, there are no administrative commissions in their list (article 5 of the Law).

Thus, the system of subjects of administrative jurisdiction includes authorized bodies (officials) of public authority, court (judges) (in terms of resolving cases of administrative offenses), bodies and structures of local selfgovernment.

The interested subject - the person brought to responsibility, the victim and their legal representatives (parents, adoptive parents, guardians, Trustees, lawyers). Unlike the subjects of the first group, none of the representatives of this group does not enjoy authority ${ }^{11}$.

The personality of the offender is characterized primarily by the signs inherent in the subject of the offense (age, sex, official, social status, illegal behavior in the past), as well as behavior in the workforce and at home, attitude to family, colleagues, school, and the like. All these circumstances must be established by the body (official), considering the case, to have a full idea of the identity of the offender.

The rights of stakeholders should include:

1. The right to get acquainted with the materials of the case, except for those with limited access. Such materials include official documents of the leading entity confidential materials. The confidential nature of the information must be recognized by the lead entity or wire. Information may be considered confidential if its disclosure may cause harm to the interested

11 Course of administrative law of Ukraine: Textbook / V. Kolpakov, O. Kuzmenko, I. Pastukh, V. Sushchenko, etc. 2nd ed., processing. and extra. Kyiv: Yurinkom Inter, 2013. $872 \mathrm{p}$. 
person who provided it, or / and other participants in the process. A leading entity may deny access to confidential information if it is determined that a person has divulged sensitive data.

2. The right to produce evidence. 3. The right to invite experts and provide expert opinions.

3. The right to submit petitions, oral and written explanations (objections), statements.

4. The right to object to the petitions of other interested persons.

7. The right to participate in the proceedings conducted by the leading actors (in particular, the preparation of an act of offense, including in hearings held at the stage of investigation).

8. The right to appeal the decision.

Responsibilities of stakeholders are: 1) conscientiously exercise their corresponding rights; 2) timely provide to its leading entity the necessary information; 3) as jurisdictional, and positive processes sometimes provides for the obligation of the presence on stage of the case.

Responsibility of interested persons for non-performance of duties:

1) accelerated adoption of the final decision, in fact, less favorable for the interested person (if the interested person evades cooperation with the leading entity-does not give access to information, does not provide it in a timely manner, hinders the investigation).

Applicant. The applicant is the person who filed the application, the body (official) makes representations about the violation of the legislation.

Disinterested subjects - persons and bodies that facilitate the implementation of the proceedings: a lawyer, witnesses, experts, specialists, translators, witnesses and the like.

A lawyer or other specialist in the field of law, who has the right to provide legal assistance in person or on behalf of a legal entity, may get acquainted with the case materials, submit petitions, on behalf of the person who invited him, on her behalf, bring complaints against the decision on the case. His powers to participate in the consideration of the case are certified by the relevant document confirming the right to provide legal assistance ${ }^{12}$.

Witness. A witness is a person about whom there is evidence that he knows any circumstances to be established in the case under consideration.

The witness participates in exceptional cases. A civil servant as an impartial subject of law unilaterally fixes the circumstances of the case. However, it is necessary to provide for a wider involvement of witnesses to record the circumstances that are the leading actors. Interesting is the combination of the

${ }^{12}$ Kolpakov V. Administrative-tort process: studies. benefit. / Kolpakov V., Gordeev V. Kharkiv: Kharkiv legal, 2012. 227 p. 
status of a witness and an interested person. Thus, when considering a case of violation of the legislation on protection of economic competition, the Antimonopoly Committee bodies receive explanations from any persons who are not participants in the case) at their request. And in the other case, the law defines the circle of such interested witnesses. National commissions on regulation of natural monopolies, when making decisions on such regulation, take into account information on the activities of a natural monopoly subject provided by consumer associations, natural monopoly subjects, and other interested parties. This does not raise the question of admission to the production of such an interested witness. For example, on personal reception citizens can come with relatives, others, at will persons who have direct relation to the questions raised in the statement of such citizen. At the same time, the term "witnesses" is rarely used due to the fact that the vast majority of disinterested persons receive information due to their social status. First of all, we are talking about officials. But with regard to citizens, it is really worth using the term witnesses.

The duties of the witness include: 1) to appear at the call of the leading subject or the wire; 2) to give a truthful explanation; 3) to report the circumstances known to him in the case and answer the questions posed".

Expert. The expert is appointed by the body (official) considering the case when there is a need for special knowledge. Examination can be carried out by an expert of a special institution, individual experts, expert commissions. Thus, the Antimonopoly legislation provides for the granting by the Cabinet of Ministers of Ukraine of permission for concerted actions only in the presence of the conclusion of the Commission from among independent experts with a positive assessment of the consequences of such actions'.

To the rights of the expert are: 1) the right to request him to review the case materials relating to the subject of examination if it is necessary to give an opinion; 2) the right to refuse to give conclusions if provided materials are not enough or not necessary knowledge to complete the examination; 3 ) the right to request additional materials necessary to give an opinion; 4) to put the person concerned, the witness questions which relate to the subject of examination, to be present at the resolution of the case.

The duties of the expert include: 1) the duty to be responsible for refusing to give an opinion without good reason; 2) the duty to be responsible for the disclosure of information with limited access".

Others (translators, witnesses) are needed to consolidate evidence or provide the necessary conditions for administrative proceedings.

Translator. This participant in the proceedings is engaged by the leading entity (wire) at the request of the person concerned, who does not speak the language in which the proceedings are conducted, or on his own initiative in the interests of ensuring a complete and accurate translation, which he is entrusted. 
The translator, who is appointed in case of need by the body (official) considering the case, is obliged to appear at the call of the latter and make the translation fully and accurately entrusted to him.

Witnesses. An adult person who is not interested in the outcome of a case and participates in the proceedings to certify its fact, progress and results in cases established by the SCCR is understood ${ }^{13}$.

A witness has the right: 1) to know the conduct of procedural actions he is involved, who runs it and who participates; 2) to do about procedural acts in which he participates, the statements and comments that shall be included in the minutes of the procedural action; 3 ) the transcript of the procedural action in which he participated, and to require corrections and additions; 4) to sign the minutes of the procedural action in the part, which reflects perceived personally the circumstances;

5) to receive compensation for the expenses incurred by him related to participation in the proceedings. A witness is obliged: 1) to report on the claim of an official of the body conducting administrative process, information about the relationship of persons in administrative proceedings; 2) certify with his signature the minutes of the procedural action, the fact that the production of this action, its progress and results; 3 ) observe the procedure in the production of procedural actions; 4) to obey the lawful orders of the officers of the body conducting administrative process.

The defendant may be questioned as a witness about the circumstances related to the proceedings in which he took part.

Specialists. These include specialists of non-governmental organizations operating in the field, subjected to individual legal regulation (for example, specialists of self-regulatory organizations).

Another type of specialists are specialists who simultaneously present their views on the legal qualification of circumstances. The participation of such specialists is necessary to obtain reasonable assessments and conclusions about the legality of the actions of officials in respect of whom an internal investigation is appointed.

This group also includes public organizations, labor collectives, administration at the place of work, study or residence of offenders. They cooperate with the state authorities, helping them in the implementation of educational work. In some cases, such participants in the proceedings must be informed about the administrative measures taken against the perpetrators. They can apply for mitigation of administrative responsibility. A person who has committed an offense may be released from administrative responsibility

${ }^{13}$ Kolpakov V. Administrative-tort process: studies. benefit. / Kolpakov V., Gordeev V. Kharkiv: Kharkiv legal, 2012. 227 p. 
with the transfer of materials for consideration by a public organization or a labor collective.

Thus, the proceedings in cases of administrative violations has a wide range of subjects, which are guaranteed the relevant rights and freedoms. Detailed regulation of relations between subjects of jurisdiction and participants of the specified production is a guarantee of objective resolution of legal disputes which arise, in exact accordance with the legislation. The easier and bezkonfliktnishe relationship between a citizen and the state in the face of its bodies and officials, the calmer and more secure he feels, resulting in increased law-abiding, respect for the state and its bodies, increases the authority of the latter.

\section{CONCLUSIONS}

The concept of the subject of administrative process. Classification of subjects of administrative process. Features of administrative legal personality of individuals and legal entities, civil servants (employees of local governments) and officials who are endowed with administrative and procedural rights and duties (administrative and procedural legal capacity, administrative and procedural capacity). General characteristics of administrative-procedural legal personality of other subjects of administrative process. The distinction between the concepts "subject" and "participant" of the administrative process.

\section{SUMMARY}

In the General theoretical understanding, the subject is recognized (from the Latin-the one who is at the heart), the carrier of subject-practical activity and knowledge (an individual or a social group), the source of activity aimed at the object.

In turn, in the theory of law, the subject of law is a person (natural or legal) that by law has the ability to have and implement directly or through a representative of the rights and legal obligations (that is, legal personality).

Legal personality, which includes legal capacity and legal capacity, is vested in both subjects of material administrative-legal relations and subjects of procedural administrative-legal relations.

Administrative-procedural legal capacity is the ability to have legal rights and obligations in the administrative process. It is recognized for all citizens of Ukraine, foreigners, stateless persons, as well as for public authorities, other state bodies, authorities of the Autonomous Republic of Crimea, local authorities, their officials and officials, enterprises, institutions, organizations that are legal entities. 
Administrative procedural legal capacity arises in citizens from the moment of their birth and is terminated by death. For legal entities, it arises from the moment of their creation and ends with their liquidation. To participate in the administrative process, in addition to the General administrative procedural legal capacity, it is also necessary to have a specific administrative procedural legal capacity, that is, in this particular case.

In order to personally participate in the consideration of an administrative case, it is not enough to have only administrative procedural legal capacity. Possession of administrative procedural capacity is also necessary for the participant of the case.

Administrative-procedural capacity is the ability to personally exercise their administrative procedural rights and obligations, including to entrust the conduct of the case to a representative.

The administrative process is characterized by a variety of subjects. As parties (participants, subjects) in the administrative process are legal entities and individuals; Executive and administrative bodies of the state and local self-government; administrations of enterprises, institutions, organizations and public organizations; political parties and bodies of public initiative; Association of citizens and ordinary citizens, as well as foreigners and stateless persons and others.

The analysis of the whole array of participants of administrativeprocedural relations allows us to identify five groups of subjects of administrative process:

1) citizens;

2) Executive and administrative bodies and structural parts of their apparatus;

3) Association of citizens and their bodies, as well as bodies of selforganization of the population having administrative and procedural legal personality;

4) civil servants and officials vested with administrative and procedural rights and duties;

5) other state bodies and their officials.

\section{REFERENCES}

1. Administrative justice. Administrative proceedings: studies.benefit. / T. Kolomoets, G. Gulevskaya, R. Sinelnik. Kiev: Istina, 2007. 152 p.

2. Administrative law: textbook / Y. Bytyak, etc.; the NAT. Yuri. Acad. Ukraine them. Yaroslav The Wise. Kharkiv: Pravo, 2010. 624 p. 
3. Administrative law of Ukraine. Vol. 1: General administrative law textbook: in 2 volumes / Galunko V. et al. Kherson: PJSC "Kherson city printing house", 2011. $320 \mathrm{p}$.

4. Administrative procedural (judicial) law of Ukraine: Studies. / Odessa national law Academy / S. Kivalov (Ed.). Odessa: Legal literature, 2017. $312 \mathrm{p}$.

5. Administrative and legal protection of citizens ' rights: studies.method. possib. / K. Afanasiev et al.; Lugan. state University EXT. cases to them. E. Didorenko. Lugansk : RIO LGUSD them. E. Didorenko, 2011. 279 p.

6. Administrative procedural law of Ukraine: Textbook. / Edited by O. Kuzmenko. Kyiv: Atika, 2007. 416 p.

7. Bandurka O. Administrative process: Textbook for the University / O. Bandurka, M. Tishchenko. Kiev: Litera LTD, 2002. 286 p.

9. Demsky E. Administrative procedural law of Ukraine: studies. no. I E. Demsky. Kyiv: Yurinkom Inter, 2008. 496 p.

10. Kolpakov V. Administrative responsibility (administrative-tort law): Textbook / V. Kolpakov. Kyiv: Yurinkom Inter, 2008. 256 p.

11. Kolpakov V. Administrative-tort process: studies. benefit. / Kolpakov V., Gordeev V. Kharkiv: Kharkiv legal, 2012. 227 p.

12. ComSoc A. Administrative process of Ukraine : textbook. no. I ComSoc A. T., V. Bevzenko R. Miller. Kiev : A Precedent, 2007. 531 p.

13. Kuzmenko E. in Administrative-procedural law of Ukraine: textbook. Kyiv: Atika, 2007. 416 p.

14. Kuzmenko O. Administrative justice in Ukraine: textbook. Kyiv: Atika, 2007. 156 p.

15. Kuzmenko O. The Course of the administrative process: proc. benefit. NATs. Acad. EXT. cases'. Kyiv: Yurinkom Inter, 2014. 207 p.

16. Perepelyuk V. Administrative process. General part: Tutorial. Kyiv: center of educational literature, 2004. $367 \mathrm{p}$.

17. Administrative law: textbook / NU "YUAU im. Yaroslav the Wise"; for zag. ed: Y. P. bytyak, V. Garashchuk, V. Zui. 2nd ed., Rev. and additional. Kharkiv: Pravo, 2013. 56 p.

18. Administrative procedural law: studies. no. / Dnepropetr. state University EXT. del; for zag. ed. Kharkiv: Pravo, 2013. $352 \mathrm{~s}$

19. The code of Ukraine on administrative offences dated 7 December 1984, No. 8073-x URL: http://zakon4.rada.gov.ua/laws/show/80731-10

20. Course of administrative law of Ukraine: Textbook / V. Kolpakov, O. Kuzmenko, I. Pastukh, V. Sushchenko, etc. 2nd ed., processing. and extra. Kyiv: Yurinkom Inter, 2013. 872 p. 
21. Scientific and practical commentary of the Code of Ukraine on administrative offences / G. Kalyuzhny, N. Inshin, I. Shopina, etc. - fifth Edition, with amendments and additions as of September 10, 2013 Kyiv: Alerta, 2013. $976 \mathrm{p}$.

22. Kuzmenko O. Course of administrative responsibility. Textbook. Kyiv: Yurinkom Inter, 2015. 568 p.

\section{Information about the author:}

Popovich Ye. M.,

Doctor of Law, Professor,

Professor at the Department of Administrative,

Criminal Law and Procedure, International University of Business and Law 37-A, 49 HGD str., Kherson, 73040, Ukraine 